\title{
Projected impact of global warming on the distribution of two pocket mouse species with implications on the conservation of Heteromys nelsoni (Rodentia: Heteromyidae)
}

\author{
Consuelo Lorenzo $^{1 *}$, Tamara Rioja-Paradela ${ }^{2}$, Arturo Carrillo-Reyes ${ }^{3}$, Eugenia Sántiz-López ${ }^{4}$ \\ \& Jorge Bolaños-Citalán ${ }^{1}$ \\ 1. Departamento de Conservación de la Biodiversidad, El Colegio de la Frontera Sur, Carretera Panamericana y \\ Periférico Sur s/n, Barrio María Auxiliadora, CP 29290, San Cristóbal de Las Casas, Chiapas, México; \\ clorenzo@ecosur.mx, jbolanos@ecosur.mx \\ 2. Posgrado en Desarrollo Sustentable y Gestión de Riesgos, Universidad de Ciencias y Artes de Chiapas, ${ }^{\text {a }}$. Sur \\ Poniente 1460, CP 29039, Tuxtla Gutiérrez, Chiapas, México; tamara.rioja@unicach.mx \\ 3. Oikos: Conservación y Desarrollo Sustentable A.C., Bugambilias 5, Bismark, CP 29267, San Cristóbal de Las Casas, \\ Chiapas, México; arturocarrilloreyes@gmail.com \\ 4. Área Sistemas Socio-ecológicos. Centro de Investigación en Ciencias de Información Geoespacial (CENTROGEO), \\ Contoy 137, Col. Lomas de Padierna, Tlalpan, CP 14240, Ciudad de México, México; esantiz@centrogeo.edu.mx \\ * Correspondence
}

Received 23-II-2019. C Corrected 12-VI-2019. Accepted 24-IX-2019.

\begin{abstract}
Introduction: Understanding how species respond to climate change is critical for implementing conservation strategies. Objective: We explain through potential distributions and changes in altitudinal variation, the possible impacts of climate change in an endangered micro-endemic rodent of Mexico with narrow altitudinal range, Heteromys nelsoni and a rodent with a wide distributional and altitudinal range, Heteromys goldmani. Methods: We obtained historical and current records of both Heteromys species. Potential distribution models were generated using Maxent, including altitudes for each species and bioclimatic layers. We determined the Extent of Occurrence and Area of Occupancy for H. nelsoni according to the criteria of the IUCN in order to generate information about its risk status. Results: The altitude is not a variable that determines a shift in the distribution caused by climate change. In contrast, the temperature and precipitation are important for the potential distribution of both Heteromys species. The future changes in climatic conditions could reduce the area of suitable habitat for both species. Conclusions: The distribution surface is not greater than $33.44 \mathrm{~km}^{2}$ for $H$. nelsoni. Therefore, is urgent to re-evaluate their conservation status by the IUCN, mainly in its B criterion, and to take specific actions for their conservation. We suggest the creation of a terrestrial protected area.
\end{abstract}

Key words: area of occupancy, extent of occurrence, potential distribution, climate change, distribution range, rodents.

Lorenzo, C., Rioja-Paradela, T., Carrillo-Reyes, A., Sántiz-López, E., \& Bolaños-Citalán, J. (2019). Projected impact of global warming on the distribution of two pocket mouse species with implications on the conservation of Heteromys nelsoni (Rodentia: Heteromyidae). Revista de Biología Tropical, 67(6), 1210-1219.

The Nelson's spiny pocket mouse, Heteromys nelsoni Merriam, 1902, is a monotypic endemic species with an extent of occurrence of around $4650 \mathrm{~km}^{2}$ (Cuarón \& Vázquez, 2018). This species has been reported at elevations from $2480 \mathrm{~m}$ to $2850 \mathrm{~m}$ in discontinuous patches of cloud forests in Pinabeto (type locality) and Cerro Mozotal in Chiapas, Mexico and in Volcán Tajumulco in Guatemala (Rogers \& Rogers, 1992; Patton, 2005; Reid, 2009; Cuarón 
\& Vázquez, 2018). Only two populations of $H$. nelsoni are known to occur in Chiapas both in mountain peaks, geographically isolated by a large valley of $25 \mathrm{~km}$ with a difference in altitude of $1600 \mathrm{~m}$, and known by a few specimens deposited in biological collections (Ríos, Lorenzo, \& Álvarez-Castañeda, 2016): 1) in the vicinity of Cerro Mozotal (municipalities El Porvenir and Siltepec), and 2) in the location of Pinabeto (municipality Motozintla).

Heteromys nelsoni is listed as endangered by the International Union for Conservation of Nature (IUCN, 2018) and is under special protection by the Mexican Government (SEMARNAT, 2010). Main threats for $H$. nelsoni are: 1) habitat loss and degradation in relation to human activities, which has evidenced some grade of demographic contraction in part of its distribution (e.g., Cerro Mozotal, Chiapas; Ríos et al., 2016); 2) stochastic events such as storms and flooding (Cuarón \& Vázquez, 2018); and 3) global warming, which can cause contraction in its restricted distribution range (Rogers \& Rogers, 1992).

Understanding how species respond to climate change is critical for implementing conservation strategies (Thomas et al., 2004; Rull \& Vegas-Vilarrúbia, 2006; Cahill et al., 2013). Climate change usually favor the presence of species that can expand their distribution range (Levinsky, Skov, Svenning, \& Rahbek, 2007; Moritz et al., 2008), but endemic and some narrowly distributed species are less likely to be in equilibrium with climate (Levinsky et al., 2007) and exhibit some characteristics that are expected to increase a species' sensitivity to climate change (Walther et al., 2002; Thomas et al., 2004). Some examples include low fecundity, poor dispersal capability, high energetic requirements, narrow thermoneutral zone, and obligate relationship to a naturally patchy habitat (Smith \& Weston, 1990). Moritz et al. (2008) report the contraction of the distribution range of four species of mountain mammals and the collapse of two other species. (Mcdonald \& Brown, 1992) also report the disappearance of three species of mountain mammals for the Great Basin in Western North America.
In Mexico, climate change models show that there is a tendency of a $10-28 \%$ precipitation decrease (2090) and a temperature increase (2050) of 1.5-2 ${ }^{\circ} \mathrm{C}$ (Banco Mundial, 2013), and while this may decrease the distribution range of some narrow distributed species, testing this hypothesis is very difficult since there are several factors that act at different spatial scales (Araújo, Thuiller, \& Pearson, 2006). One of the predicted biological responses to global warming is the upslope displacement of the species. There are often local endemic species in tropical mountain ranges that are distributed near the summits, which may be especially vulnerable to the total loss of habitat due to global warming (Raxworthy-Christopher et al., 2008). However, the vulnerability of most tropical mountain species to extinction has not been well documented (Rull \& Vegas-Vilarrúbia, 2006).

In this paper, we attempt to explain the possible impacts of future climate change projections on the distribution of two small mammal species by modeling its potential distributions and altitudinal range variation. We expect the potential distribution of $H$. nelsoni to decrease due to its restricted distribution to highlands, while that of $H$. goldmani increases due to its wide distribution. These results can be used to re-assess the conservation status of the species and to propose conservation policies, considering specific areas of $H$. nelsoni occurrence, since having this kind of information it is fundamental to be able to establish conservation strategies to reduce the loss of biodiversity and protect important functions in the ecosystem (Mouillot et al., 2013).

\section{MATERIALS AND METHODS}

Historical records of $H$. nelsoni and $H$. goldmani were obtained from the Global Biodiversity Information Facility (GBIF, 2018), as well as the data base of the Colección Mastozoológica of El Colegio de la Frontera Sur at San Cristóbal de Las Casas, Chiapas, México. Additionally, field monitoring was carried out in August and November, 2017 
and February-March, 2018 in sampling sites of Pinabeto, Chiapas, $22.6 \mathrm{~km}$ away (in a straight line) from Cerro Mozotal, Chiapas (Fig. 1).

A total of 43 specimens were captured using Sherman traps. In Mozotal, 22 sampling days were carried out for a total of 2720 trapsnight, while in Pinabeto, 13 sampling days were carried out for a total of 1500 traps-night. The external measures were registered for each individual (total lengths of body, tail, hind leg and ear), weight, sex, reproductive condition, habitat type and geographical position with a manual GPS (Garmin eTrex Vista, Kansas, USA). The two species can be distinguished by characteristics such as: the fur of $H$. nelsoni does not have hard bristles, H. goldmani has a lateral line that does not have $H$. nelsoni. At the skull, H. nelsoni has the upper third molar is equal to or wider than the premolar, while in
H. goldmani the upper third molar is narrower than the premolar (Álvarez-Castañeda, Álvarez, \& González-Ruiz, 2017). All capture and handling methods followed the animal care and use guidelines of the American Society of Mammalogists (Sikes et al., 2016).

Potential distribution models were generated using Maxent v.3.4.1 (Phillips \& Dudík, 2008). A Pearson correlation analysis was made between all layers, and all those with a significant correlation higher than 0.7 were discarded (Gormley et al., 2011). All duplicate records, as well as those less than $1 \mathrm{~km}$ away from each other were discarded (Velasco et al., 2016). We used remaining $H$. nelsoni (33 records) and $H$. goldmani (136 records), including altitudes for each one and the bioclimatic layers (version 1.4) generated (Hijmans, Cameron, Parra, Jones, \& Jarvis, 2005). A first model

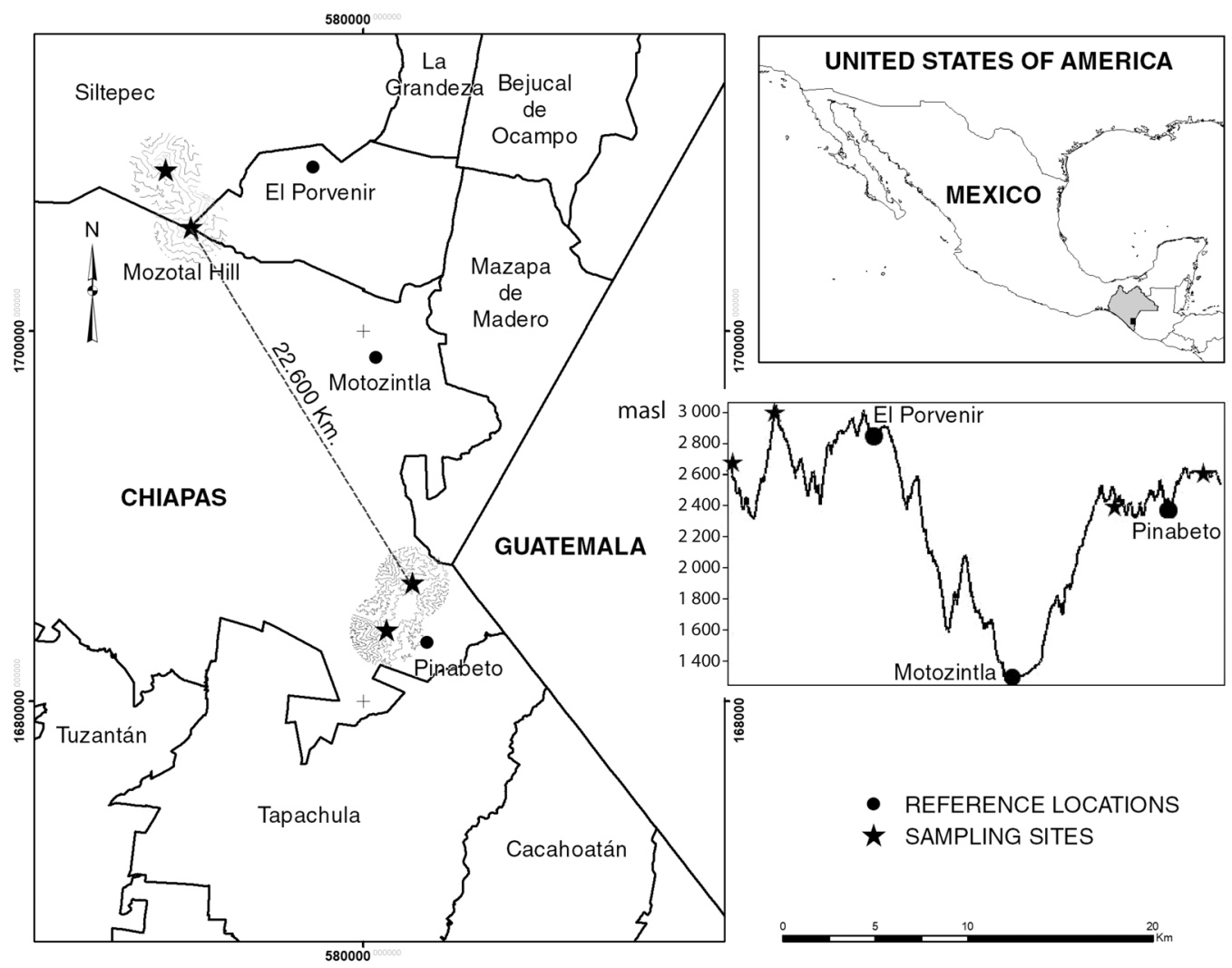

Fig. 1. Sampling sites of Heteromys nelsoni in southern Chiapas (stars). The upper right image shows the region of sampling sites in southeastern México and western Guatemala. The lower right image shows the altitudinal differences in the sampling sites. 
with ten replicates was executed to identify the variables with a contribution greater than $0.5 \%$ (Warren, Wright, Seifert, \& Shaffer, 2014) and with greater importance for the model according to the Jackknife test of variable importance (which tests the highest gain environmental variable when used in isolation). Layers which did not meet these requirements were discarded. Finally, ten replicate models were run with a random seed to produce distinct modelto-model variation using the bootstrap type (Peterson et al., 2015) and a maximum of 500 iterations, holding out $25 \%$ of the samples for testing in each run of the model. Models were evaluated through the Area under the curve (AUC) and the ROC graphics (Hanley $\&$ McNeil, 1982). To reduce uncertainty, the best five models were chosen (highest AUC and lowest omission rate, Table 1), each one was transformed to a binary map considering the logistic threshold of the 10th percentile of the training data (10 percentile training presence, Proosdij, Sosef, Wieringa, \& Raes, 2016). Subsequently, we made a multiplication of these models using map algebra to obtain a consensus map of the current potential distribution for each species (consensus approach,
Aguirre-Gutiérrez et al., 2013). Additionally, following the same procedure, we projected the potential distribution of $H$. nelsoni and $H$. goldmani for the years 2050 and 2070. The bioclimatic layers of (Hijmans et al., 2005) were used for the HadGEM2-ES (one of the major models used in the IPCC Third Assessment Report) and CCSM4 (the Community Climate System Model) models. These are two of the main models used in similar analyzes. We used the calculations of the RCP85 scenario (Representative Concentration Pathways) for both models. This scenario estimates that greenhouse gas emissions continue to rise throughout the $21^{\text {st }}$ century, with an estimated increase of $3.7^{\circ} \mathrm{C}$ for the year 2070 (IPCC, 2013).

Additionally, the Extent of Occurrence (EOO; area contained within the shortest continuous imaginary boundary which can be drawn to encompass all the known, inferred or projected sites of present occurrence of a taxon, excluding cases of vagrancy) and Area of Occupancy (AOO; area within its extent of occurrence which is occupied by a taxon, excluding cases of vagrancy) was determined according to the criteria of the IUCN through Criterion B1 (geographic range in the form

TABLE 1

Mean and standard deviation (d.s.) of AUC values from training and test data

\begin{tabular}{|c|c|c|c|c|}
\hline \multirow{3}{*}{$\begin{array}{l}\text { Models } \\
\text { Present }\end{array}$} & \multicolumn{4}{|c|}{ Species } \\
\hline & \multicolumn{2}{|c|}{ H. nelsoni } & \multicolumn{2}{|c|}{ H. goldmani } \\
\hline & Mean & d.s. & Mean & d.s. \\
\hline Training & 0.9899 & 0.0091 & 0.9707 & 0.0020 \\
\hline Test & 0.9871 & 0.0169 & 0.9650 & 0.0066 \\
\hline \multicolumn{5}{|c|}{ CCSM4 for 2050} \\
\hline Training & 0.9907 & 0.0083 & 0.9649 & 0.0050 \\
\hline Test & 0.9979 & 0.0024 & 0.9650 & 0.0103 \\
\hline \multicolumn{5}{|c|}{ CCSM4 for 2070} \\
\hline Training & 0.9913 & 0.0066 & 0.9732 & 0.0047 \\
\hline Test & 0.9828 & 0.9291 & 0.9582 & 0.0179 \\
\hline \multicolumn{5}{|c|}{ HadGEM2-ES for 2050} \\
\hline Training & 0.9882 & 0.0076 & 0.9714 & 0.0028 \\
\hline Test & 0.9974 & 0.0014 & 0.9649 & 0.0128 \\
\hline \multicolumn{5}{|c|}{ HadGEM2-ES for 2070} \\
\hline Training & 0.9915 & 0.0051 & 0.9640 & 0.0071 \\
\hline Test & 0.9900 & 0.0168 & 0.9531 & 0.0169 \\
\hline
\end{tabular}


of extent of occurrence estimated to be less than $5000 \mathrm{~km}^{2}$ ) and B2 (geographic range in the form of area of occupancy estimated to be less than $500 \mathrm{~km}^{2}$, IUCN, 2012; IUCN Standards and Petitions Subcommittee, 2017). This, in order to generate information about the risk status of $H$. nelsoni, maintains consistency with the Red List assessments. For EOO, we created a convex shell for all recent records of both species. For AOO, we created a $2 \times 2 \mathrm{~km}$ grid for Chiapas (Mexico) and Guatemala. Then, records of both species were placed, and the number of grids of $4 \mathrm{~km}^{2}$ within which there were records of the species was calculated. All analysis was developed using QGis software v.3.2 (QGIS Development Team, 2018).

\section{RESULTS}

Bioclimatic variables such as Annual Mean Temperature $\left({ }^{\circ} \mathrm{C}\right)$ and Precipitation of Driest Month $(\mathrm{mm})$ significantly determined the distribution of $H$. nelsoni. The same happened when modeling the distribution of $H$. goldmani, finding that bioclimatic variables such as Temperature Seasonality and Mean Diurnal Range can explain the distribution of this species (Table 2).

As expected, the present maximum suitability area of $H$. goldmani is greater than that of H. nelsoni, and there is no overlap in both species distributions. In projections to future scenarios, for $H$. nelsoni the size of its area of maximum suitability shows a slight decrease with CCM4 model (17.94\%) for 2070, while increase with HadGEM2-ES model (23.08 \%) for 2070. For H. goldmani, the size of its area of maximum suitability shows a slight increase with CCM4 model (4.94\%) for 2070, while decrease with HadGEM2-ES model (28.29\%) for 2070 (Table 3; Fig. 2).

The EOO analysis show an area of $8077.32 \mathrm{~km}^{2}$ for $H$. goldmani and $487.47 \mathrm{~km}^{2}$ for $H$. nelsoni. According to AOO analysis, $H$. nelsoni has a $32 \mathrm{~km}^{2} \mathrm{AOO}$, and $H$. goldmani a $160 \mathrm{~km}^{2}$ AOO (Fig. 3).

\section{DISCUSSION}

Cuarón and Vazquez (2018) reported an extent of occurrence for $H$. nelsoni of about $4650 \mathrm{~km}^{2}$. In contrast, our field records and the potential distribution analysis show a distribution surface no greater than $33.44 \mathrm{~km}^{2}$ according to one of the used models. Until now there is no evidence of the presence of $\mathrm{H}$. nelsoni in the protected area of the Tacaná Volcano Biosphere Reserve in Chiapas, Mexico, which coincides with the result of its potential distribution, which does not predict suitable habitat

TABLE 2

Percent of contribution of each principal variable in tested models of potential distribution for H. nelsoni and H. goldmani

\begin{tabular}{clc}
\multicolumn{1}{c}{ Species } & \multicolumn{1}{c}{ Variable } & \multicolumn{1}{c}{ Percent contribution (\%) } \\
Heteromys nelsoni & Annual Mean Temperature $\left({ }^{\circ} \mathrm{C}\right)$ & 59.1 \\
& Precipitation of Driest Month $(\mathrm{mm})$ & 18.3 \\
& Isothermality & 10.9 \\
& Mean Diurnal Range & 7.5 \\
& Mean Temperature of Coldest Quarter $\left({ }^{\circ} \mathrm{C}\right)$ & 4.2 \\
Heteromys goldmani & & 44.1 \\
& Temperature Seasonality & 33.3 \\
& Mean Diurnal Range & 14.1 \\
& Precipitation of Warmest Quarter $(\mathrm{mm})$ & 8.5 \\
\hline
\end{tabular}

Mean Diurnal Range: Mean of monthly (max temp - min temp); Isothermality: (Mean Diurnal Range/Temperature Annual Range)*100; Mean Diurnal Range: Mean of monthly (max temp - min temp); Temperature Seasonality (standard deviation*100); Precipitation Seasonality (Coefficient of Variation); a quarter is a period of three months (1/4 of the year). 
TABLE 3

Maximum suitability area $\left(\mathrm{km}^{2}\right)$ of $H$. nelsoni and H. goldmani, for the CCSM4 and HadGEM2-ES models in the RCP85 scenario

\begin{tabular}{lccc} 
& \multicolumn{3}{c}{ Species } \\
& Year & Heteromys nelsoni & Heteromys goldmani \\
CCSM4 & Present & 33.44 & 3952.67 \\
& 2050 & 37.73 & 3489.57 \\
HadGEM2-ES & 2070 & 27.44 & 4148.21 \\
& 2050 & 62.6 & 2800.92 \\
& 2070 & 41.16 & 2834.36
\end{tabular}
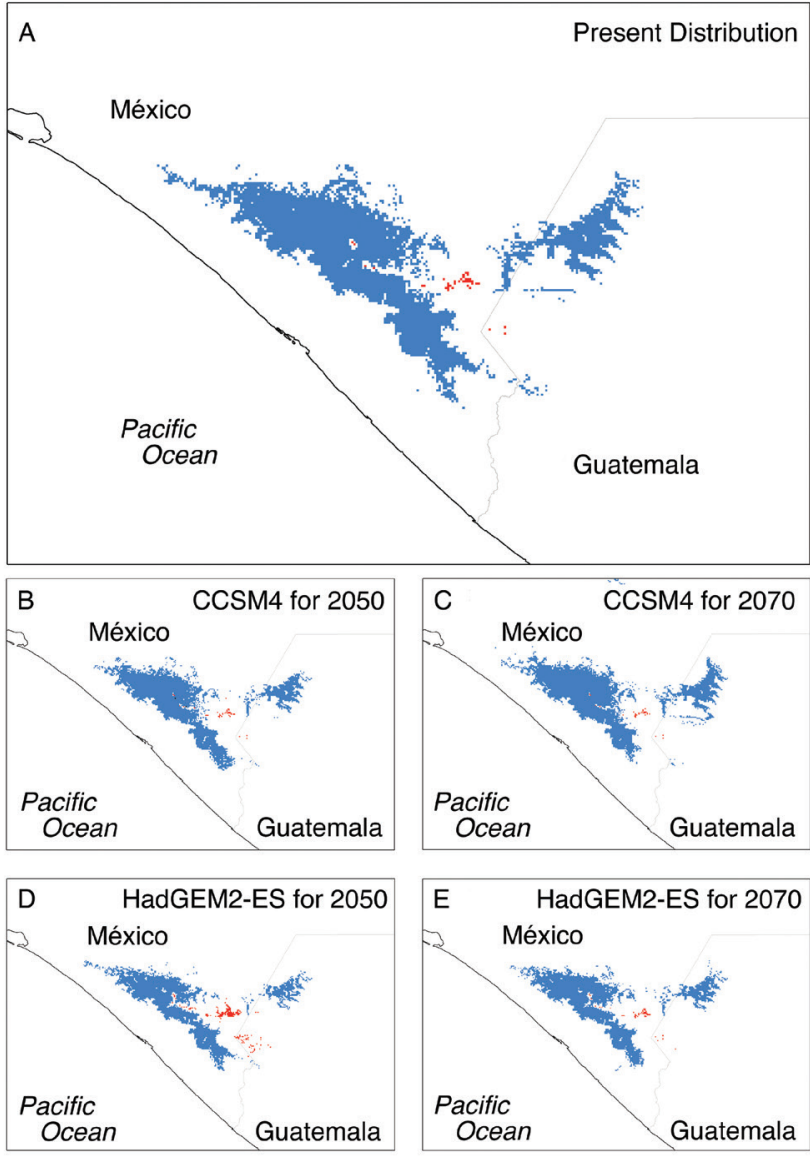

Fig. 2. Maximum suitability area for Heteromys nelsoni (black) and H. goldmani (light gray) for the two models tested.

sites in the Tacaná Volcano area. An ecological study of mammals in the Tacaná region at altitudes of less than $2000 \mathrm{~m}$ does not mention the presence of this species (Mendoza-Sáenz \& Horváth, 2013). This result implies that the habitat available for the species is much smaller than what has been described.

Heteromys nelsoni exists between 2480 and $2850 \mathrm{~m}$; Lorenzo, Bolaños-Citalán, \& Retana-Guiascón, 2019), and H. goldmani 

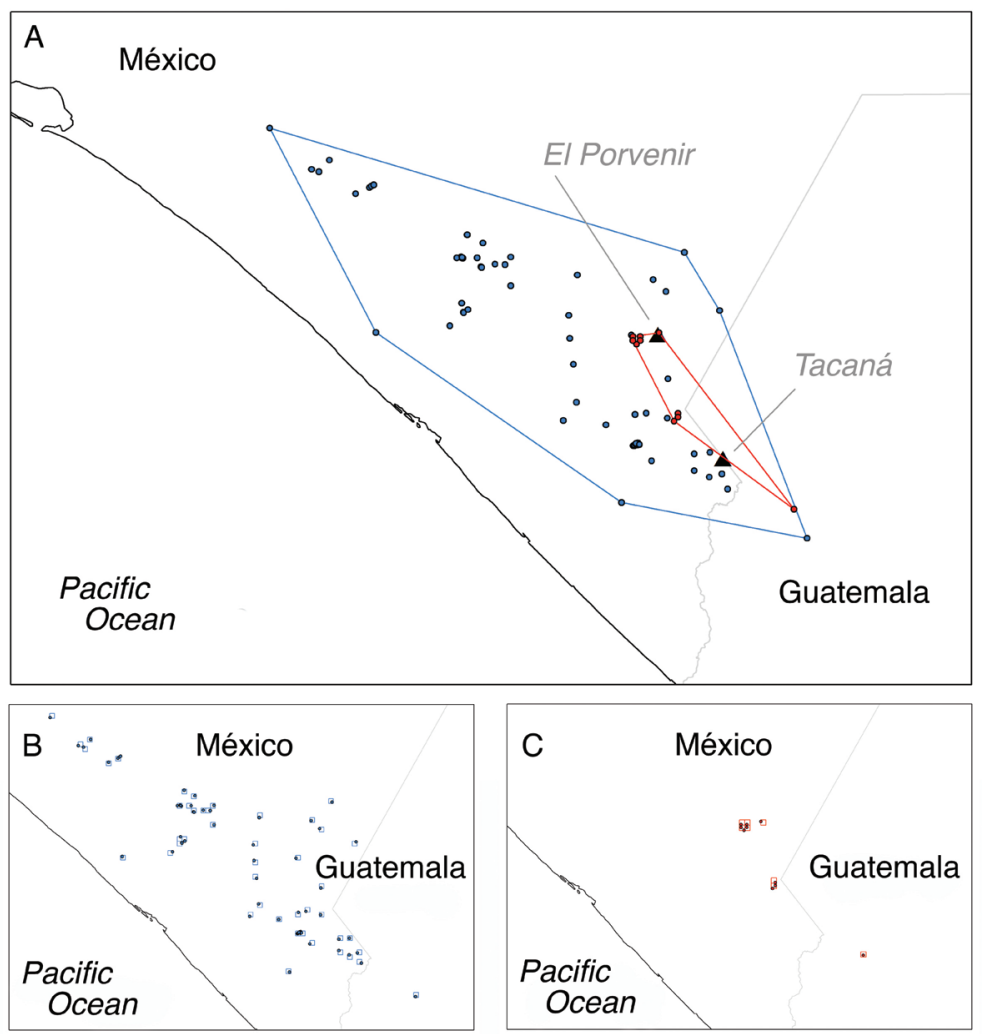

Fig. 3. Records of H. goldmani (light gray) and H. nelsoni (black), in study area. Extent of Occurrence (EOO) is shown for both species (A). AOO for H. goldmani (B) and H. nelsoni (C) is shown, whit $2 \times 2 \mathrm{~km}$ grid for all records.

between $1250 \mathrm{~m}$ and $2680 \mathrm{~m}$ (Ríos, Lorenzo, \& Álvarez-Castañeda, 2016). This difference in altitude was not important for the potential distribution models (its contribution value was low and highly correlated with other bioclimatic variables). Therefore, it seems like altitude is not a variable that determines a shift in these species distribution. In contrast, the bioclimatic variables, such as temperature and precipitation are important for the potential distribution of the Heteromys species under study. Our results indicate that future changes in climatic conditions will reduce the area of suitable habitat for $H$. nelsoni and will favor the presence of $H$. goldmani. This trend can be observed with the two models tested.

Heteromys goldmani, previously considered a subspecies of the widely distributed $H$. desmarestianus, but genetically differentiated and supported as a valid species (Rogers \& González, 2010; Álvarez-Castañeda et al., 2012), has been registered in coffee plantations, pine-oak forests and patches of cloud forest in Cerro Mozotal and also patches of cloud forest in Pinabeto (Ríos et al., 2016). It is a habitat generalist species, and it is expected to benefit from future climate change (Levinsky et al., 2007; Moritz et al., 2008), which is supported by our models that indicate an increase in its distributional range (its distribution area could be extended up to $4.74 \%$ in by 2070 , according to the CCSM4 model). However, in case the climate conditions predicted by the HadGEM2-ES model are registered in 2070, this species could also be affected by climate change, despite being a generalist species.

On other hand, $H$. nelsoni only occurs in the mountain peaks of the Sierra Madre de Chiapas, 
which present unique bioclimatic conditions that do not allow it to occur in other areas. This mouse is restricted to cloud forests (Rogers \& Rogers, 1992), which is an endangered habitat due to unrestricted logging, extensive livestock farming and fire, and presents a low genetic diversity with a very recent demographic contraction in the population of Cerro Mozotal (Ríos et al., 2016). This specialist habitat species is expected to be negatively affected from future climate change (Walther et al., 2002; Thomas et al., 2004; Levinsky et al., 2007), which is supported by our models. Although models show an increase of available area for H. nelsoni in 2050, these models also show a similar trend with a reduction of the available area by 2070 . By geographically projecting the areas of maximum suitability for $H$. nelsoni, the increase in temperature seems to create new available sites in a higher altitudinal range. Probably, the availability of habitat for this species is favored by promoting the presence of certain species that form its habitat (Liu, Kumar, Katul, \& Porporato, 2018; Mitchell et al., 2018). However, the prediction for 2070 is a reduction in the size of areas of maximum suitability, probably due to limitations in the altitudinal range, limiting the areas where the species could take refuge. This demonstrates the need to make longer-term projections for these species.

For both species, temperature was the most important variable, measured through the effect of bioclimatic variables. For $H$. nelsoni the Annual Mean Temperature $\left({ }^{\circ} \mathrm{C}\right)$ contributed $59.1 \%$ to explain its distribution, and for $H$. goldmani the Temperature Seasonality contributed with $44.1 \%$. This is something reported in previous studies, where the temperature and its derivatives in the bioclimatic variables had a significant effect on the size of the future potential distribution of the species. This seems to be explained mainly by the direct effect of temperature on the distribution of habitat, refuge or food for the species of interest (Fernández \& Hamilton, 2015; Bradie \& Leung, 2016; Sántiz, Lorenzo, Carrillo-Reyes, Navarrete, \& Islebe, 2016; King, Karoly, \& Henley, 2017).
It is evident that the $\mathrm{EOO}$ and $\mathrm{AOO}$ values are closer to the IUCN criterion for critically endangered species than to the criteria for endangered species. Considering the bias of this criterion, by not considering non-habitable areas for species of punctual distribution, as is the case with $H$. nelsoni (IUCN Standards and Petitions Subcommittee, 2017), we suggest this species status be reevaluated mainly in its $\mathrm{B}$ criterion (geographic range in the extent of occurrence and/or area of occupancy), and to take specific actions for the conservation of the species and its habitat. We also suggest that the creation of a terrestrial protected area for this species is urgent.

Ethical statement: authors declare that they all agree with this publication and made significant contributions; that there is no conflict of interest of any kind; and that we followed all pertinent ethical and legal procedures and requirements. All financial sources are fully and clearly stated in the acknowledgements section. A signed document has been filed in the journal archives.

\section{RESUMEN}

Proyección del impacto del calentamiento global sobre la distribución de dos especies de ratones de abazones: implicaciones en la conservación de Heteromys nelsoni (Rodentia: Heteromyidae). Introducción: El entendimiento de cómo las especies responden al cambio climático es crítico para la implementación de estrategias de conservación. Objetivo: Explicar a través de distribuciones potenciales y cambios en la variación altitudinal, los posibles impactos del cambio climático en un roedor micro endémico de México, en peligro de extinción y con un rango altitudinal estrecho, Heteromys nelsoni y un roedor con una amplia distribución y rango altitudinal, Heteromys goldmani. Metodología: Obtuvimos registros históricos y actuales de ambas especies. Los modelos de distribución potencial se generaron utilizando Maxent, incluyendo altitudes y capas bioclimáticas. Determinamos la extensión de su presencia y el área de ocupación para $H$. nelsoni según los criterios de la IUCN, para generar información sobre su estado de riesgo. Resultados: La altitud no es una variable que determina un cambio en la distribución causada por el cambio climático. En contraste, la temperatura y precipitación son importantes para la distribución potencial de ambas especies de Heteromys. Los análisis sugieren que los cambios futuros en las condiciones climáticas podrían 
reducir el área de hábitat adecuado para ambas especies. Conclusión: La superficie de distribución de H. nelsoni no es mayor a $33.44 \mathrm{~km}^{2}$. Es urgente reevaluar su estado de conservación de la UICN, principalmente en su criterio B y tomar medidas específicas para su conservación. Sugerimos la creación de un área terrestre protegida.

Palabras clave: área de ocupación, distribución potencial, extensión de presencia, cambio climático, rango de distribución, roedores.

\section{REFERENCES}

Aguirre-Gutiérrez, J., Carvalheiro, L. G., Polce, C., van Loon, E. E., Raes, N., Reemer, M., \& Biesmeijer, J. C. (2013). Fit-for-Purpose: Species Distribution Model Performance Depends on Evaluation Criteria - Dutch Hoverflies as a Case Study. PLoS ONE, 8(5). DOI: 10.1371/journal.pone.0063708

Álvarez-Castañeda, S. T., Álvarez, T., \& González-Ruiz, N. (2017). Keys for Identifying Mexican Mammals ( $1^{\text {st }}$ ed.). Baltimore: The Johns Hopkins University Press.

Álvarez-Castañeda, S. T., Lorenzo, C., Ríos, E., CortésCalva, P., Elías, M., Ortega, J., \& Cervantes, F. A. (2012). DNA Barcoding of mammals in Mexico: Implication for diversity. The Open Zoology Journal, $5,18-26$.

Araújo, M. B., Thuiller, W., \& Pearson, R. G. (2006). Climate warming and the decline of amphibians and reptiles in Europe. Journal of Biogeography, 33, $1712-1728$.

Banco Mundial. (2013). Las dimensiones sociales del cambio climático en México ( $1^{\text {st }} \mathrm{ed}$.). Unidad Administrativa del Sector de Desarrollo Sustentable Región de América Latina y el Caribe.

Bradie, J., \& Leung, B. (2016). A quantitative synthesis of the importance of variables used in MaxEnt species distribution models. Journal of Biogeography, 44, 1344-1361.

Cahill, A. E., Aiello-Lammens, M. E., Fisher-Reid, M. C., Hua, X., Karanewsky, C. J., Ryu, H. Y., ... Wiens, J. J. (2013). How does climate change cause extinction? Proceedings. Biological Sciences, 280(1750), 20121890. DOI: $10.1098 / \mathrm{rspb} .2012 .1890$

Cuarón, A. D., \& Vázquez, E. (2018). Heteromys nelsoni. The IUCN Red List of Threatened Species 2018. Retrieved from https://www.iucnredlist.org/ species/10009/22223445

Fernández, M., \& Hamilton, H. (2015). Ecological niche transferability using invasive species as a case study. PLOS ONE, 10: e0119891.
GBIF. (2018). What is GBIF? GBIF: The Global Biodiversity Information Facility. Retrieved from https:// www.gbif.org/what-is-gbif

Gormley, A. M., Forsyth, D. M., Griffioen, P., Lindeman, M., Ramsey, D. S., Scroggie, M. P., \& Woodford, L. (2011). Using presence-only and presence-absence data to estimate the current and potential distributions of established invasive species. The Journal of Applied Ecology, 48(1), 25-34. DOI: 10.1111/j.1365-2664.2010.01911.x

Hanley, J. A., \& McNeil, B. J. (1982). The meaning and use of the area under a receiver operating characteristic (ROC) curve. Radiology, 143(1), 29-36.

Hijmans, R. J., Cameron, S. E., Parra, J. L., Jones, P. G., \& Jarvis, A. (2005). Very high resolution interpolated climate surfaces for global land areas. International Journal of Climatology, 25(15), 1965-1978. DOI: 10.1002/joc. 1276

IPCC. (2013). Climate Change 2013: The Physical Science Basis. Working Group 1 (WG1) Contribution to the Intergovernmental Panel on Climate Change (IPCC) $5^{\text {th }}$ Assessment Report (AR5) ( $1^{\text {st }}$ ed.). Retrieved from https://web.archive.org/web/20140812170932/http:// www.ipcc.ch/report/ar5/wg1

IUCN. (2012). IUCN Red List Categories and Criteria (Version 3.1.) ( $2^{\text {nd }}$ ed.). UK, Gland, Switzerland, \& Cambridge: IUCN.

IUCN. (2018). The IUCN Red List of Threatened (Species Version 2018). Retrieved from http://www.iucnredlist.org

IUCN Standards and Petitions Subcommittee. (2017). Guidelines for using the IUCN Red List Categories and Criteria (Version 13). International Union for Conservation of Nature. Retrieved from http://www. iucnredlist.org/documents/RedListGuidelines.pdf

King, A. D., Karoly, D. J., \& Henley, B. J. (2017). Australian climate extremes at $1.5^{\circ} \mathrm{C}$ and $2{ }^{\circ} \mathrm{C}$ of global warming. Nature Climate Change, 7, 412-416.

Levinsky, I., Skov, F., Svenning, J. C., \& Rahbek, C. (2007). Potential impacts of climate change on the distributions and diversity patterns of European mammals. Biodiversity and Conservation, 16(13), 3803-3816. DOI: 10.1007/s10531-007-9181-7

Liu, Y., Kumar, M., Katul, G.G., \& Porporato, A. (2018, August). Reduced resilience as a potential early warning signal of forest mortality. Ecological Society of America Annual Meeting. New Orleans, Louisiana.

Lorenzo, C., Bolaños-Citalán, J., \& Retana-Guiascón, O. G. (2019). Rediscovery of Heteromys nelsoni in its type locality after over a century. Mammalia. DOI: 10.1515/mammalia-2018-0154 
Mcdonald, K. A., \& Brown, J. H. (1992). Using Montane Mammals to Model Extinctions Due to Global Change. DOI: 10.1046/j.1523-1739.1992.06030409.x

Mendoza-Sáenz, V. H., \& Horváth, A. (2013). Rodents and bats in the coffee zone from Tacaná Volcano, Chiapas, Mexico. Therya, 4, 409-423.

Mitchell, M. G. E., Johansen, K., Maron, M., McAlpine, C. A., Wu, D., \& Rhodes, J. R. (2018). Identification of fine scale and landscape scale drivers of urban aboveground carbon stocks using high-resolution modeling and mapping. Science of the Total Environment, 622623, 57-70. DOI: 10.1016/j.scitotenv.2017.11.255

Moritz, C., Patton, J. L., Conroy, C. J., Parra, J. L., White, G. C., \& Beissinger, S. R. (2008). Impact of a Century of Climate Change on Small-Mammal Communities in Yosemite National Park, USA. Science, 322(5899), 261-264. DOI: 10.1126/science.1163428

Mouillot, D., Bellwood, D. R., Baraloto, C., Chave, J., Galzin, R., Harmelin-Vivien, M., ... Thuiller, W. (2013). Rare species support vulnerable functions in highdiversity ecosystems. PLoS Biology, 11(5), e1001569. DOI: 10.1371/journal.pbio.1001569

Patton, J. L. (2005). Family Heteromyidae. In D. E.Wilson \& D. M. Reeder (Eds.), Mammals species of the world. A taxonomic and geographic reference $\left(3^{\text {rd }}\right.$ ed., pp. 844-852). Baltimore, M. D., E.U.A: Johns Hopkins University.

Peterson, A. T., Navarro-Sigüenza, A. G., Martínez-Meyer, E., Cuervo-Robayo, A. P., Berlanga, H., \& Soberón, J. (2015). Twentieth century turnover of Mexican endemic avifaunas: Landscape change versus climate drivers. Science Advances, 1(4), e1400071. DOI: 10.1126/sciadv. 1400071

Phillips, S. J., \& Dudík, M. (2008). Modeling of species distributions with Maxent: new extensions and a comprehensive evaluation. Ecography, 31(2), 161175. DOI: $10.1111 /$ j.0906-7590.2008.5203.x

Proosdij, A. S. J. van, Sosef, M. S. M., Wieringa, J. J., \& Raes, N. (2016). Minimum required number of specimen records to develop accurate species distribution models. Ecography, 39(6), 542-552. DOI: 10.1111/ ecog.01509

QGIS Development Team. (2018). Quantum GIS Geographic Information System (Version 3.2). Retrieved from http://qgis.osgeo.org

Raxworthy, C. J., Pearson, R. G., Rabibisoa, N., Rakotondrazafy, A. M., Ramanamanjato J. B., Raselimanana, A. P., ... Stone, D. A. (2008). Extinction vulnerability of tropical montane endemism from warming and upslope displacement: a preliminary appraisal for the highest massif in Madagascar. Global Change Biology, 14(8), 1703-1720. DOI: 10.1111/j.1365-2486.2008.01596.x
Reid, F. (2009). A Field Guide to the Mammals of Central America and Southeast Mexico (2 ed.). Oxford, New York: OUP USA.

Ríos, E., Lorenzo, C., \& Álvarez-Castañeda, S. T. (2016). Genetic variation in Heteromys nelsoni (Rodentia: Heteromyidae) reveals its possible natural extinction. Mammalia, 81(3), 289-296. DOI: 10.1515/ mammalia-2015-0173

Rogers, D. S., \& González, M. W. (2010). Phylogenetic relationships among spiny pocket mice (Heteromys) inferred from mitochondrial and nuclear sequence data. Journal of Mammalogy, 91, 914-930.

Rogers, D. S., \& Rogers, J. E. (1992). Heteromys nelsoni. Mammalian Species, 397, 1-2.

Rull, V., \& Vegas-Vilarrúbia, T. (2006). Unexpected biodiversity loss under global warming in the neotropical Guayana Highlands: a preliminary appraisal. Global Change Biology, 12, 1-9.

Sántiz, E. C., Lorenzo, C., Carrillo-Reyes, A., Navarrete, D. A., \& Islebe, G. (2016). Effect of climate change on the distribution of a critically threatened species. Therya, 7(1), 147-159. DOI: 10.12933/therya-16-358

SEMARNAT. (2010). Norma Oficial Mexicana NOM059-SEMARNAT-2010. Protección ambiental-Especies nativas de México de flora y fauna silvestres-Categorías de riesgo y especificaciones para su inclusión, exclusión o cambio-Lista de especies en riesgo. PROFEPA.

Sikes, R. S., Bryan, J. A. I., Byman, D., Danielson, B. J., Eggleston, J., Gannon, M. R., ... Willoughby, J. R. (2016). 2016 Guidelines of the American Society of Mammalogists for the use of wild mammals in research and education. Journal of Mammalogy, 97(3), 663-688.

Smith, A. T., \& Weston, M. L. (1990). Ochotona princeps. Mammalian Species, 352, 1-8.

Thomas, C. D., Cameron, A., Green, R. E., Bakkenes, M., Beaumont, L. J., Collingham, Y. C., ... Williams, S. E. (2004). Extinction risk from climate change. Nature, 427, 145.

Velasco, J. A., Martínez-Meyer, E., Flores-Villela, O., García, A., Algar, A. C., Köhler, G., \& Daza, J. M. (2016). Climatic niche attributes and diversification in Anolis lizards. Journal of Biogeography, 43(1), 134-144. DOI: $10.1111 /$ jbi.12627

Walther, G. R., Post, E., Convey, P., Menzel, A., Parmesan, C., Beebee, T. J. C., ... Bairlein, F. (2002). Ecological responses to recent climate change. Nature, 416, 389.

Warren, D. L., Wright, A. N., Seifert, S. N., \& Shaffer, H. B. (2014). Incorporating model complexity and spatial sampling bias into ecological niche models of climate change risks faced by 90 California vertebrate species of concern. Diversity and Distributions, 20(3), 334-343. DOI: 10.1111/ddi.12160 